DOI: https://doi.org/10.34069/AI/2021.47.11.22

How to Cite:

Kobzar, O., Romanov, M., Benkovskyi, S., Povzyk, Y., \& Trach, S. (2021). Principles for pre-trial investigation planning under simplified procedure. Amazonia Investiga, 10(47), 216-225. https://doi.org/10.34069/AI/2021.47.11.22

\title{
Principles for pre-trial investigation planning under simplified procedure
}

\section{Засади планування досудового розслідування за спрощеною процедурою}

Received: October 30, 2021
Accepted: November 28, 2021

\section{Abstract}

The purpose of the article is to study the organizational and legal framework for the functioning of the institution of pre-trial investigation planning under simplified procedure. The subject of the study is the planning of a pre-trial investigation under simplified procedure. Methodology. General scientific and special scientific methods were used in the course of the research: formal and logical; description; historical and legal; comparative and legal; dogmatic. Results of the research. The concept, essence, as well as the basic scientific doctrines concerning functioning of institution of planning are investigated; the content of the legal support for pre-trial investigation under simplified procedure is clarified. Practical meaning. The content and essence of the relevant process in the context of pre-trial investigation under simplified procedure are outlined; the main elements of legal support for the functioning of this institution are allocated; the author's view on the positive and negative features of pre-trial investigation planning as the management tool is provided. Value / originality. The further steps to optimize the functioning of the institution of planning for
Анотація

Метою статті $є$ досліджено організаційноправові засади функціонування інституту планування досудового розслідування за спрощеною процедурою. Предметом дослідження $\epsilon$ планування досудового розслідування за спрощеною процедурою. Методологія Під час дослідження застосовано загальнонаукові та спеціальнонаукові методи: формальної логіки; опису; історико-правовий; порівняльно-правовий; догматичний. Результати дослідження. Досліджено поняття, сутність, а також основні наукові доктрини щодо функціонування інституту планування; 3'ясовано зміст нормативно-правового забезпечення досудового розслідування за скороченою процедурою. Практичне значення. Окреслено зміст і сутність відповідного процесу в контексті здійснення досудового розслідування за скороченою процедурою, а також охарактеризовано основні елементи нормативно-правового забезпечення функціонування цього інституту, а також виокремлено авторську позицію, щодо позитивних і негативних рис планування досудового розслідування, як інструменту менеджменту. Цінність /

\footnotetext{
${ }^{93}$ Doctor of Law, Professor, Head of the Department of Law Enforcement of the National Guard of Ukraine, Kyiv Institute of the National Guard of Ukraine, Ukraine.

${ }^{94}$ Senior Research Fellow of Public Law Research Department of the Scientific Institute of Public Law, Ukraine.

${ }^{95} \mathrm{PhD}$ in Law, Head of the Department of State Law Disciplines, Kyiv Institute of the National Guard of Ukraine, Ukraine.

${ }^{96} \mathrm{PhD}$ in Law, Assistant at the Department of Criminal Justice of Yaroslav Mudryi National Law University, Ukraine.

${ }^{97} \mathrm{PhD}$ in Law, Senior Lecturer of the Department of Criminal Procedure of the National Academy of Internal Affairs, Ukraine.
} 


\section{AMAZONDA
Drvestiga}

pre-trial investigation of criminal offenses are proposed.

Key words: organization of work, planning, pretrial investigation, criminal offenses, inquiries, investigation by simplified procedure, administrative law.

\section{Introduction}

The Ukrainian law enforcement system, as well as global mechanisms to ensure human and civil rights and freedoms, is aimed at responding to violations of the foundations of the institution, as well as bringing to justice those responsible and restoring the rights and freedoms of victims.

Rapid, complete, impartial pre-trial investigation of criminal offenses and illegal encroachments is one of the main tasks of the State, which, in our opinion, can be done only through the planned, gradual and methodical law enforcement activities of authorized government officials and their employees.

At the same time, given that the process of pretrial investigation of criminal offenses has certain chronological limitations, depending on the stage of pre-trial investigation, as well as the severity of the offense and other related legal factors, the issues of advance planning of investigative (search) actions, as well as adoption of procedural decisions are quite relevant in the modern world.

The relevant issue becomes even more acute in the context of the functioning of the institution of inquiry, which has its own procedure and individual procedural deadlines based on the content of its "simplification".

That is why, in our opinion, this issue needs more in-depth study in terms of administrative law, as well as the development of possible ways to solve pressing organizational problems.

The purpose of the article is to analyze the scientific views of researchers and scientists on the essence and content of pre-trial investigation planning under a simplified procedure, as well as to study Ukrainian legislation for circumstances and conditions affecting pre-trial investigation of criminal offenses. This goal necessitated the solution of a number of research tasks, including: research of the concept, essence and basic оригінальність. Винесено на обговорення пропозиції, щодо подальших кроків оптимізації функціонування інституту планування досудового розслідування кримінальних проступків.

Ключові слова: організація роботи, планування, досудове розслідування, кримінальні проступки, дізнання, розслідування за спрощеною процедурою, адміністративне право.

scientific doctrines on the functioning of the institution of planning; clarification of the content of regulatory and legal support of pretrial investigation under simplified procedure; establishing the relationship between the deadlines in the pre-trial investigation under simplified procedure; clarification of the main international trends regarding the institution of pre-trial investigation planning under simplified procedure; outlining the problems and developing recommendations for possible solutions and improving the relevant institution.

\section{Methodology}

During the research general scientific and special scientific methods were used. Formal and logical method was applied for establishing the main problems of the functioning of the institution and proposing the possible ways to solve them. The method of description helped to determine general theoretical and administrative and legal categories that characterize the institution of planning of pre-trial investigation under simplified procedure. Historical and legal method made it possible to highlight the evolution of the views of scientists on the institution of planning of pre-trial investigation under simplified procedure. With the help of comparative and legal method the relevant administrative law and criminal procedural norms and scientific provisions relating to the issues under consideration were analyzed. Dogmatic method was used to interpret the main legal categories and clarify the conceptual and categorical apparatus of the research.

The object of this study is public relations in the area of organizational and legal framework for the functioning of inquiry units of the National Police of Ukraine. The subject matter of the study is the planning of a pre-trial investigation under simplified procedure. 


\section{Literature Review}

Given the polydisciplinarity of the subject matter of the research, it should be noted that the issues of organizational and legal support for law enforcement agencies studied such scholars as: Bespalko (2018) (article "Definition of the concept of general principles in criminal proceedings"); Hres (2017) (Thesis "Shaping of technological approach in criminalistic tactics"), Drozd et al. (2021) (monograph "Inadmissibility of evidence in criminal proceedings: Analysis of investigative practice through the lens of court decisions"); Maliuha (2016) (Thesis "Interaction of the investigator with operational units and other entities in the system of methods of investigating crimes"); Khan (2021) (monograph "Theoretical principles of planning and organization of crime investigation"); Tsutskiridze (2020) (monograph "Criminal procedural activities of the investigator: theory and practice"), Cherniavskyi et al. (2019) (guidelines on pre-trial investigation of criminal offenses), etc.

The works of some foreign scientists are used for the clarification of the concept of planning in pretrial investigation. For example, Newman (1963, p. 56) state that many scholars do not separate planning from management, arguing that both planning and management are essentially the same - making decisions about future activities. This view is shared by other researchers, who argue that planning is about gaining control over the future; not only thinking about the future, but also acting actively towards it (Fayol 1949, p. 43). Ackoff (1970, p. 73) believes that planning is the development of the desired future, as well as ways, in which it could be implemented, which includes identifying alternatives, analyzing each of them and choosing the best one. Mintzberg (1994), researching the mechanism of strategic planning, notes that the term "planning" is used as the synonym for "decision making" and "project management" in some sources.

\section{Results and Discussion}

Given that the subject of this scientific article is the administrative and legal aspect of planning pre-trial investigation as a management process in the field of protection of human rights and freedoms through criminal and criminal procedural rules, but the lack of comprehensive scientific study of basic forensic characteristics will significantly affect the final start directly with their characteristics.
It should also be noted that the concept of principles, including organizational and legal ones, is quite often considered quite often, but its content and essence is extremely important in the context of the study of the outlined topic.

Bespalko (2018, p. 53), researching these issues emphasizes that the principles of law are the starting points that legally fix the objective laws of social development.

Besides, the integral category of "organizational and legal support" or "organizational and legal framework" has repeatedly appeared in the research of scientists. For example, Pryimachenko ta Ihonin (2013, p. 60) argue that any elements relating to organizational and legal principles should be of security nature, form legal and organizational foundation for the implementation of certain actions, which in turn are procedural in nature.

Shahanenko (2015, p. 146), researching the issues of organizational support for the prosecutor's office, points out that the signs of such a process are the availability of personnel measures; information and operational activities. However, in our opinion, these elements, in addition to what can be absorbed by the other topics proposed, in turn do not belong to the same synonymous series, but on the contrary are partly mutually supportive.

This, first of all, creates a proper scientific and information basis for the analysis of these provisions in terms of mutual coherence and complimentarily. However, the variability of approaches to the concept of planning, in turn, also creates a certain legal inaccuracy.

Newman (1963, p. 56) state that many scholars do not separate planning from management, arguing that both planning and management are essentially the same - making decisions about future activities. At the same time, we support the author's position on the difference between these terms, because from a logical point of view management characterizes the activities here and now, and planning, allows pre-define management decision-making for certain variables in the future.

This view is shared by other researchers, who argue that planning is about gaining control over the future; not only thinking about the future, but also acting actively towards it (Fayol 1949, p. 43). This opinion is still relevant. This position gives grounds to substantiate that planning is an 


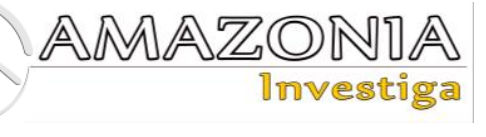

active, dynamic process of managing a certain process taking into account various factors, including, above all, decision-making, where each subsequent is or partially following from the previous one.

Ackoff (1970, p. 73) believes that planning is the development of the desired future, as well as ways, in which it could be implemented, which includes identifying alternatives, analyzing each of them and choosing the best one. That is, from the perspective of organizational and legal support for planning, the legislator should first of all provide for the possibility of implementing the mechanism of prosecution in such a way that it functions as a whole and indivisible system, which in turn makes it possible to plan such activities. Given the legal certainty and the existence of established legal traditions (for example, taking into account court decisions on key issues of investigation of the relevant bodies) it is possible and promising to implement planning that will optimize pre-trial investigation by grouping issues, allocating key tasks and setting clear deadlines.

Mintzberg (1994), researching the mechanism of strategic planning, notes that the term "planning" is used as the synonym for "decision making" and "project management" in some sources. Besides, the researchers of strategic planning of enterprise development, make their own specific but common sense in the planning period and understand it as one of the main management functions, the process of defining goals that the company intends to achieve over time, as well as means, ways and conditions for their implementation. That is, pre-trial investigation under simplified procedure, which in turn is an integral part of the institution of human and civil rights and freedoms in the context of procedural deadlines, is one of the main issues of sustainable and effective project management.

Considering the basic principles of planning, Fayol (1949) pointed out that the correct program of actions includes the ultimate goal, control line of behavior, stages of future activities and tools that will be used. Defining the structural elements of planning most clearly and structurally, having clarified the appropriate approaches to the planning of pre-trial investigation directly, we propose to apply them to establish the structural features of pre-trial investigation planning in a simplified form in the future.

Along with the analyzed definitions, we believe that it is most appropriate to pay attention to the fact that the concept of planning of pre-trial investigation in forensic researches is considered somewhat differently, which is proposed to integrate into the material of this scientific work.

Belkin (1997, p. 373) once argued that proper planning of the investigation in each case ensures compliance with all basic principles of the investigation: objectivity, comprehensiveness, completeness, efficiency, initiative, activity of the investigation, and as the result - high quality investigation. Planning ensures the use of the necessary methods of investigation, sets the boundaries of the investigation, organizes the activities of the investigator, requiring him (her) to be thoughtful. This, in our opinion, clearly reflects the essence of planning in the pre-trial investigation, which in turn can not be equated with planning in other areas; material or financial damage to the enterprise due to ineffective management (management planning) leads to disciplinary or civil liability, while improper implementation of the pre-trial investigation entails not only disciplinary but also criminal liability, as such actions may entail, in addition to reasons of poor competence, the signs of corruption or negligence.

Along with this, some researchers draw attention to the investigator's inductive conclusion in the form of a presumption based on factual data about the crime and its individual circumstances, which is subject to verification by logical rules of deduction (Yakushyn 1983, p. 55). Along with this, Belkin (1997, p. 207) understands planning in investigation as "determining the ways of solving crimes, outlining the circumstances to be clarified". That is, the scientists emphasize that the process of planning a pre-trial investigation differs from the typical planning, primarily because it has certain limits, as well as a number of mandatory elements, the successful implementation of which leads to further implementation of planned activities (clear analogy is the need to submit information to the Unified Register of Pre-trial Investigations, which reveals opportunities for other investigative (search) actions, except for site inspections).

Drapkin (1994, p. 230) and Larin (1970, p. 59) draw attention to the fact that the content and functions of planning is the complex process to determine the ways, means, forces and deadlines for successful achievement of intended goals, which in turn are interdependent and based on investigation plan. The points of the plan of such an investigation, are first of all, signal points of progressive achievement. $\mathrm{We}$, in turn, fully 
support the proposed opinion, as the authors stress that planning of pre-trial investigation, including in simplified form, is characterized by deadlines, violation of which entails serious liability.

Pantelieiev and Selivanov (1988, pp. p. 334-335) state that in order to organize the activity it is necessary to plan it, prepare, adjust, organize and monitor its implementation. Organization of the investigation is the broader concept than planning; the latter is only one of its elements.

Krylov (1976, p. 297) interprets the term "investigation" as narrower than "planning", which involves creating the conditions necessary for the effective work of the investigator: premises, communications, transport, maintenance, application, scientific justification of the mode of operation, correct forms of accounting and reporting. This gives grounds to limit the time of the pre-trial investigation and determine that planning is really an element of the organization, which in turn includes the ability to further predict the results of the pre-trial investigation, which is very important in the context of shorter periods of inquiry.

Konovalova (1973, p. 26) notes that the planning of the investigation means determining the ways to solve crimes, outlining the circumstances to be clarified, as well as establishing the most appropriate time for investigative (search) actions and covert investigative (search) actions. Kolisnychenko (1973, p. 178) recognizes planning as cognitive process, which aims to identify all the necessary circumstances of the case under investigation, to establish the truth in the proceedings. At the same time, in our opinion, planning cannot include only reasonable dates for implementation necessary investigative (search) actions and covert investigative (search) actions, as the pre-trial investigation process is much more complex than just conducting procedural actions and recognizing planning as a cognitive process partially contradicts the mechanism of this measure, because, in essence, planning is carried out using available information that allows to construct further actions and predict risks and hazards (i.e., this process is implemented through analyzed information available in the pre-trial investigation).

Baiev (1977, p. 139) stated that planning is aimed at identifying tasks that need to be solved at certain stages of the study, mostly in terms of verifying the versions formulated by the entity planning to investigate crimes and ways to solve these problems. That is, planning, in turn, in the presence or absence of certain recorded circumstances and facts in the pre-trial investigation is a certain procedural algorithm of step-by-step approach to its final stage. In turn, being limited by some features, this algorithm is extremely multifunctional, as when conducting pre-trial investigation in simplified form, the investigator can achieve efficiency not only in one criminal case, but in several ones. Simultaneous pre-trial investigation, even under simplified procedure, seems possible and, moreover, effective in the context of proper planning based on the available circumstances and facts, which in no way harms the interests of the prosecution.

The elements of the planning of pre-trial investigation in general and in simplified form are several components, on the content of which the researchers have their own, authors' views.

Dubrovytska (1972, p. 5) names the elements of planning to determine the purpose and objectives of the investigation for each of the stages and the choice of the most effective and economical ways to solve these problems. Luzghin (1972, p. 31) includes the study of factual data to the elements of planning, drawing up the program for the investigation, defining the tasks of the investigation and ways to solve them. In our opinion, it is extremely positive in the context of effective planning of pre-trial investigation under simplified procedure to establish the primary element of the offense - the circumstances and the fact of its commission, which in turn allows to determine in accordance with this goal and main tasks. It should be emphasized that depending on the circumstances of the criminal offense, the forms and methods of pre-trial investigation, which are closely related to the process of pre-trial investigation, are also changing.

Baiev (1977, p. 13) allocates the following elements of planning: finding out the possibilities at a certain stage of the investigation; defining specific goals of the plan; formulation of the main provisions of the plan; achieving the goals and selecting the best ones as the basic components of the stage of planning of prejudicial investigation. Drapkin (1987, pp. 152-155) proposes his own list of stages of planning: a) definition of immediate goals of planning; b) highlighting the common version issues; c) identification of non-version issues; d) making a decision on carrying out specific operational and investigative actions and establishing their optimal sequence; 


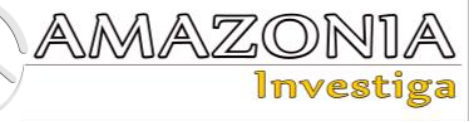

e) determination of terms, executors and duration of the planned actions; e) drawing up the agreed plan of investigation.

Given the partial uniformity of the proposed approaches, we believe that another feature of planning for pre-trial investigation under simplified procedure is the need to anticipate its flexibility and composition, as the process is quite dynamic, may temporarily restrict human and civil rights and freedoms. The result of a pretrial investigation is that the offender is brought to justice, which only increases the resistance of the defence to such a process.

That is, the organizational and legal principles of planning for pre-trial investigation under simplified procedure are those legal principles that allow regular and stable functioning of processes to determine the main purpose of pretrial investigation, establishing tasks, identification of basic steps within the period specified by the legislation of Ukraine and taking into account the regulated requirements.

This theoretical category, in our opinion, can be streamlined by highlighting the specifics of the process of simplified pre-trial investigation and indicating what exactly requires planning and which processes, in one way or another, may be factors influencing the process.

Planning is the prerequisite for the investigation; it lies in choosing the direction and optimization of tactical tasks, tools and methods for their solution in accordance with the requirements of criminal procedure law (Saltevskyi 1996, p. 317). At the same time, the issue of researching the principles of simplified pre-trial investigation and its usual procedure has been repeatedly raised in the works of domestic researchers. Thus, Drozd, Burlaka and Havryliuk (2021) point out that the activities of the investigator during pre-trial investigation should comply with the general principles of criminal procedure established by the Criminal Procedure Code of Ukraine, which is the basis for understanding European standards on the evidentiary process in criminal proceedings. The same (in the form of an inquiry) should be applied to the pre-trial investigation under simplified procedure, although this form has its own procedural features that significantly affect its planning.

For example, Cherniei and Cherniavskyi (2019) argue that the genesis and modern experience of the institution of simplified proceedings in our country and in foreign countries shows the need to further improve this procedural form, which necessitates further elaboration of problematic issues related to the organizational and legal support for the functioning of the relevant mechanism.

Officers conducting initial inquiries investigate criminal offences under simplified procedure, the duration of which should not exceed one month from the day on which the person is served with a report of suspicion (Cherniavskyi, Tsutskiridze, Dudarets, et al., 2019), because it is the time period, for which the investigator is obliged to perform all procedural actions, that essentially distinguishes inquiry as organizational process from pre-trial investigation. In our opinion, the issue of organization (need for advance planning, strategic thinking, ability to effectively allocate tasks and provide instructions) of pre-trial investigation in a short time and ensuring human and civil rights and freedoms in this process at the time of characterizing the inquiry from an administrative law point of view is the key.

The concept of "statutory period" is the main argument for the use of the planning mechanism in the pre-trial investigation, as the Criminal Procedure Code of Ukraine establishes a clear scope.

For example, Article 219 (Terms of Pre-Trial Investigation) and Article 298-4 (Features of the suspicion report) of the Criminal Procedure Code of Ukraine (Law of Ukraine No. 4651-VI) stipulate that the inquiry must be completed within 72 hours (general term) within 20 days (if the suspect pleads not guilty; there is a need for additional investigative (investigative) actions; criminal offense committed by a minor) and within 1 month if the person requested an examination within 48 hours from the date of notification of the suspect with simultaneous acquaintance with the results of medical examination and / or conclusion specialist in case of their presence from the date of notification of suspicion. That is, the process of planning for simplified pre-trial investigation has internal structural features, since by the time the person is notified of the suspicion, the period of its implementation is considerably longer than that provided after notifying the person of suspicion, because if he pleads guilty, it is 72 hours in total, which requires the most consistent and planned implementation of all necessary investigative (search) actions and the adoption of the necessary procedural decisions to ensure that such a person is prosecuted, which is impossible without the use of the planning mechanism. 
Thus, the importance of the institution of planning institute in the context of pre-trial investigation under simplified procedure is substantiated. It is a necessary tool to achieve a positive result of the pre-trial investigation and an effective way to organize the daily activities of the investigator under simultaneous pre-trial investigation of several criminal proceedings under simplified procedure.

At the same time, scholars point out that the planning of investigation in criminal proceedings should be distinguished from the planning of a separate investigative (search) action, tactical reception, tactical combination, tactical operation. Planning the investigation of a crime consists of such stages: 1) defining the tasks of the investigation taking into account the committed crime; 2) construction (nomination) of investigative versions; 3) analysis of the version and determination of circumstances (issues) that need to be established; 4) determination of investigative (search) actions, operational means and other verification and preventive measures necessary to establish the planned circumstances; 5) selection of specific performers and deadlines (Chaplynskyi, Luskatov, Pyrih, Pletenets, Chaplynska 2014).

At the same time, some provisions on planning during the pre-trial investigation, including under the simplified procedure, are also contained in the provisions of the legislation of Ukraine.

For example, Section VI of the "Regulation on the Organization of National Police Investigation Units" (Order of the Ministry of Internal Affairs of Ukraine No. 405) enshrines that the member of the Investigation Division (sector) of the Directorate-General of the National Police checks the planning of work in departments (sectors) of inquiry of territorial (separate) police units, the state of implementation of planned activities, their compliance with the plans of the department (sector) of Directorate-General of the National Police, Directorate-General of the National Police and the National Police of Ukraine, individual work plans of investigation in criminal proceedings and the state of implementation of these plans; provides practical and methodological assistance in case of shortcomings in the preparation of work plans to eliminate them; takes measures to make adjustments to work plans taking into account the changes in the operational situation.

There are any other instructions or comments concerning the process of planning a pre-trial investigation in simplified form in this
Regulation. Instead, it should be emphasized that the abovementioned normative act understands the concept of planning in several contexts, namely: the work plan of the department (sector) of inquiry of Directorate-General of the National Police; work plan of the department (sector) of inquiry; individual plan of work of the coroner, plan of investigation in criminal proceedings.

Thus, paragraphs 4 and 5, Section II of the Order "On the Organization of the activities of investigative units of the National Police of Ukraine" (Order of the Ministry of Internal Affairs of Ukraine No. 507) states that the investigator plans his or her work in such a way to ensure the implementation of all investigative (search) actions and covert investigative (search) actions in all criminal proceedings in which he conducts pre-trial investigation in a timely manner. To this end, he (she) draws up general calendar and schedule of work in all criminal proceedings, investigation and work plans in each criminal proceeding, as well as documents certifying the implementation of planned tasks (copies of analytical documents, summaries, minutes of operational meetings, certificates of inspection results, etc.), which are stored in the Investigation Unit Organization and Planning Detail.

At the same time, it should be emphasized that although these provisions are actually declared, in practice (according to the data of the Main Investigation Department of the National Police of Ukraine), an average of 373 criminal investigations were conducted by one investigator, which is a critical number of proceedings per investigator, negatively effects the quality of the pre-trial investigation and nullifies the possibility for its successful detection and prosecution of offenders (Communication Department of the National Police of Ukraine 2021).

Pre-trial investigation planning institution provides an opportunity to properly organize working hours of the investigators and inquirers and effectively perform the duties assigned to them by law, but, for example, the above Instruction does not even determine the plan of pre-trial investigation in specific criminal proceedings and individual plan of the investigator, and among the norms of the Regulations on the organization of the activities of inquiry units of the National Police of Ukraine, such norms do not exist at all. 


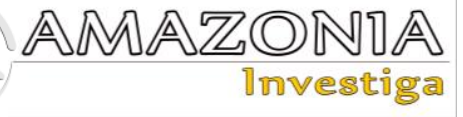

Conclusion

Thus, based on the views of domestic and foreign researchers, as well as the analysis of regulatory and legal support for the institution of pre-trial investigation planning under simplified procedure and on a general basis, the following theoretical and practical conclusions and recommendations are proposed:

1. Organizational and legal principles for planning pre-trial investigation under procedure are those principles of legal nature that allow regular and stable functioning of processes to determine the main purpose of pre-trial investigation, allocation of tasks, formation of basic further steps and measures that clearly contribute to the desired result within the period specified by the legislation of Ukraine and taking into account the regulated requirements.

2. Planning in the pre-trial investigation plays an extremely important role in view of the excessive workload of inquirers and investigators, as the effective distribution of their own working time directly affects the productivity and effectiveness of such a process and, consequently, the effectiveness of human and civil rights.

3. Regulatory and legal support for the functioning of the institution of pre-trial investigation planning under simplified procedure is currently at a low level, as its principles are only partially covered by the relevant regulations on the organization of inquiry units of the National Police of Ukraine.

4. We propose the following changes to the legal and methodological support for planning pre-trial investigation under simplified procedure:

4.1. to amend the rules of the Order "On the adoption of the Regulation on the Organization of National Police Investigation Units" governing the functioning of the institution under investigation (establish the basic principles, principles, forms and types of planning, outline the importance and significance of this process in pre-trial management);

4.2. to develop technical task for the creation of a investigator's calendar based on the Unified Register of Pre-Trial Investigations, which will significantly simplify the process of planning for pre-trial investigation in a simplified form, as well as create additional positive conditions for strengthening cooperation between the investigator and all other persons involved.

4.3. to formulate methodological recommendations on the nature, meaning and mechanism of planning in pre-trial investigation under simplified procedure, outlining its importance, basic methods and ways, and other important features in modern law enforcement realities.

5. Planning is essential because: it is the way of organizing the productivity of the working time, which helps to avoid unnecessary or ineffective steps in the investigation; correctly prioritize all planned actions from the most to the least important, taking into account the chronological criterion, which will allow the implementation of all planned activities, not just some of them; to improve the activities of the investigator in pre-trial investigation, including under simplified form.

6. The following elements are negative in the planning of the pre-trial investigation: it is not always possible to clearly define responsibilities; the dynamics of the pre-trial investigation process under simplified procedure does not allow to form static action plan; the lack of properly organized electronic document management and generally informatization of pre-trial investigation processes significantly complicates the planning process, as it is reduced to the creation of paper graphs and tables.

\section{Bibliographic references}

Ackoff, R. (1970). Concept of Corporate Planning. New York: Wiley.

Baiev, O. (1977). Forensic tactics and criminal procedure law: monograph. Voronezh: Publishing House of Voronezh University.

Belkin, R. (1997). Course of Forensics: in 3 volumes. Vol. 2: Private forensic theories. Moscow: Jurist. https://obuchalka.org/2012042064698/kurskriminalistiki-v-3-h-tomah-belkin-r-s1997.html

Bespalko, I. (2018). Definition of the concept of general principles in criminal proceedings. Enterprise, Economy and Law, No. 5, pp. 242-247. http://pgpjournal.kiev.ua/archive/2018/5/48. pdf

Chaplynskyi, K., Luskatov, O., Pyrih, I., Pletenets, V., \& Chaplynska, Yu. (2014). Forensics: textbook for students of higher educational institutions. Dnipropetrovsk: Dnipropetrovsk State University of Internal 
Affairs; Lira LTD. https://shron1.chtyvo.org.ua/Chaplynskyi_K ostiantyn/Kryminalistyka.pdf?PHPSESSID= 250o1gfe05pj92ftoc3tqpt486

Cherniavskyi, S., Tsutskiridze, M., Dudarets, R., et al. (2019). Pre-trial Investigation of Criminal Offenses: Guidelines. Kyiv: National Academy of Internal Affairs.

Cherniei, V. and Cherniavskyi, S. (2019). "Initiation of the Institution of Criminal Offenses in the Context of Reforming the Preliminary Investigation System in Ukraine". In: Scientific Bulletin of the National Academy of Internal Affairs, No. 3 (112). doi: https://doi.org/10.33270/01191123.7

Communication Department of the National Police of Ukraine (2021). Since the beginning of the year, the investigators of the National Police of Ukraine have recovered more than a billion hryvnias in damages in criminal proceedings.

https://www.npu.gov.ua/news/Informacziya/ z-pochatku-roku-slidchi-naczpoliczijizabezpechili-vidshkoduvannya-na-ponadmilyard-griven-zbitkiv-u-kriminalnixprovadzhennyax/

Drapkin, L. (1987). Fundamentals of the theory of investigative situations. Sverdlovsk: Ural Publishing House of Ural University.

Drapkin, L. (1994). Organization and planning of investigation. Moscow: Higher school.

Drozd, V., Burlaka, V., Havryliuk, L. et al. (2021). Inadmissibility of evidence in criminal proceedings: Analysis of investigative practice through the lens of court decisions: monograph. Kyiv: TOV «7BTs». https://jurkniga.ua/viznannyadokaziv-nedopustimimi-v-kriminalnomuprovadzhenni-analiz-sudovoi-praktiki-krizprizmu-sudovikh-rishen/

Dubrovytska, L. (1972). Investigation planning: textbook. Moscow: Higher School of the Ministry of Internal Affairs of the USSR.

Fayol, H. (1949). General and Industrial management. London: Pitman.

Hres, Y. (2017). Shaping of technological approach in criminalistic tactics. National University "Odessa Law Academy".

Khan, O. (2021). Theoretical principles of planning and organization of crime investigation. Odesa: Publishing House "Helvetika".

http://dspace.univd.edu.ua/xmlui/bitstream/h andle/123456789/10699/Teoretychni\%20osn ovy_monohrafiia_Khan_2021.pdf?sequence $=1 \&$ isAllowed $=\mathrm{y}$
Kolisnychenko, O. (1973). Planning of investigation and investigative versions. Kyiv: Higher School.

Konovalova V. (1973). Organization and psychological foundations of the investigator's activities. Kyiv: Ministry of Internal Affairs of the Ukrainian SSR.

Krylov, F. (1976). Forensic science: textbook. Leningrad: Publishing house of Leningrad State University.

Larin, A. (1970). Investigation of the criminal case. Planning, organization. Moscow: Legal Literature.

Law of Ukraine No. 4651-VI. Criminal Procedure Code of Ukraine. Official Web site of the Verkhovna Rada of Ukraine, April 13, 2012. Available online. https://zakon.rada.gov.ua/laws/ show / 465117.

Luzghin, I. (1972). Methodological problems of investigation. Moscow: Legal Literature.

Maliuha, V. (2016). Interaction of the investigator with operational units and other entities in the system of methods of investigating crimes. ( $\mathrm{PhD}$ Dissertation). Ivan Franko National University of Lviv, Ukraine.

Mintzberg, H. (1994). The fall and rise of strategic planning. Harvard Business Review. https://hbr.org/1994/01/the-fall-and-rise-ofstrategic-planning

Newman, W. (1963). Administrative Action: The Techniques of Organization Management. New Jersey: Englewood Cliffs.

Order of the Ministry of Internal Affairs of Ukraine No. 405. On the adoption of the Regulation on the Organization of National Police Investigation Units. Official Web site of the Verkhovna Rada of Ukraine, May 20, 2020. Available online. https://zakon.rada.gov.ua/laws/show/z049120\#Text

Order of the Ministry of Internal Affairs of Ukraine No. 507. On the organization of the activities of investigative divisions of National police of Ukraine. Official Web site of the Verkhovna Rada of Ukraine, July 06, 2017. Available online. https://zakon.rada.gov.ua/laws/show/z091817\#Text

Pantelieieva, I. \& Selivanova, N., eds. (1988). Forensic science: textbook. Moscow: Legal Literature.

Pryimachenko, D., and Ihonin, R. (2013). "The ratio of the concepts of "organizational support of courts", "organizational management in courts" and "judicial management". Word of the National School of Judges of Ukraine, No. 1, pp. $57-66$. 
http://biblio.umsf.dp.ua/jspui/handle/123456 789/3274

Saltevskyi, M. (1996). Forensics: textbook. Kyiv: Kondor.

Shahanenko, P. (2015). "The concept of organizational support for the Prosecutor's Office". Scientific Journal «Chronicles of KUL», No. 4, pp. 144 - 147.
http://kul.kiev.ua/images/chasop/2015_4/CH AS15_4.pdf

Tsutskiridze, M. (2020). Criminal procedural activities of the investigator: theory and practice. Kyiv: Alerta.

Yakushyn, S. (1983). Tactical methods in the investigation of crimes. Kazan: Kazan State University. 